\title{
Taxonomic revision and reclassification of Pseudolinosyris with related taxa in Galatella (Asteraceae)
}

\section{Sennikov, Alexander N.}

2020-10

Sennikov , A N \& Lazkov , G A 2020 , ' Taxonomic revision and reclassification of Pseudolinosyris with related taxa in Galatella (Asteraceae) ', Annales Botanici Fennici, vol. 57 , no. 4-6 , pp. 367-375 . https://doi.org/10.5735/085.057.0420

http://hdl.handle.net/10138/323388

https://doi.org/10.5735/085.057.0420

publishedVersion

Downloaded from Helda, University of Helsinki institutional repository.

This is an electronic reprint of the original article.

This reprint may differ from the original in pagination and typographic detail.

Please cite the original version. 


\title{
Taxonomic Revision and Reclassification of Pseudolinosyris with Related Taxa in Galatella (Asteraceae)
}

\author{
Authors: Sennikov, Alexander N., and Lazkov, Georgy A.
}

Source: Annales Botanici Fennici, 57(4-6) : 367-375

Published By: Finnish Zoological and Botanical Publishing Board

URL: https://doi.org/10.5735/085.057.0420

BioOne Complete (complete.BioOne.org) is a full-text database of 200 subscribed and open-access titles in the biological, ecological, and environmental sciences published by nonprofit societies, associations, museums, institutions, and presses.

Your use of this PDF, the BioOne Complete website, and all posted and associated content indicates your acceptance of BioOne's Terms of Use, available at www.bioone.org/terms-of-use.

Usage of BioOne Complete content is strictly limited to personal, educational, and non - commercial use. Commercial inquiries or rights and permissions requests should be directed to the individual publisher as copyright holder.

BioOne sees sustainable scholarly publishing as an inherently collaborative enterprise connecting authors, nonprofit publishers, academic institutions, research libraries, and research funders in the common goal of maximizing access to critical research. 


\title{
Taxonomic revision and reclassification of Pseudolinosyris with related taxa in Galatella (Asteraceae)
}

\author{
Alexander N. Sennikov ${ }^{1,2, \star}$ \& Georgy A. Lazkov ${ }^{3}$ \\ 1) Botanical Museum, Finnish Museum of Natural History, P.O. Box 7, Fl-00014 University of \\ Helsinki, Finland (“corresponding author's e-mail: alexander.sennikov@helsinki.fi) \\ 2) Herbarium, Komarov Botanical Institute of Russian Academy of Sciences, Prof. Popov Str. 2, \\ RU-197376 St. Petersburg, Russia \\ 3) Laboratory of Flora, Institute of Biology, Kyrgyz Academy of Sciences, 720071 Bishkek, Kyrgyz \\ Republic
}

Received 1 July 2020, final version received 12 Sep. 2020, accepted 14 Sep. 2020

Sennikov A.N. \& Lazkov G.A. 2020: Taxonomic revision and reclassification of Pseudolinosyris with related taxa in Galatella (Asteraceae). - Ann. Bot. Fennici 57: 367-375.

The taxonomic position of Pseudolinosyris is revised. The genus is reduced to Galatella sect. Pseudolinosyris (Novopokr.) Sennikov comb. nova. It differs from the other sections by its shorter corolla lobes and a higher level of stem lignification. Two species are recognised in this section: G. grimmii (Regel \& Schmalh.) Sennikov comb. nova, with three subspecies including $G$. grimmii subsp. microcephala (Novopokr.) Sennikov comb. nova and G. grimmii subsp. sintenisii (Bornm.) Sennikov comb. nova, and the newly added G. corymbulosa (Bornm.) Sennikov comb. nova. A further species is transferred from Crinitaria to Galatella, G. asperella (Rech. f. \& Køie) Sennikov, comb. nova to form a monotypic section Galatella sect. Asperifoliae Sennikov, sect. nova. All the species and subspecies are redescribed and mapped, and their complete synonymy with typifications and a new identification key are provided.

\section{Introduction}

The generic circumscriptions and relationships in Astereae (Asteraceae) have been subject of continuous debates. The latest synoptic works, which provide the taxonomic backbone for Asteraceae, controversially treated the Galatella group, a small group of species typical of steppe and saline lands in Eurasia. Nesom and Robinson (2007) recognized three genera in this group (Crinitaria, Galatella, Tripolium) and placed it in Asterinae, whereas Brouillet et al. (2009) moved the three genera to Bellidinae.
The monophyly and circumscription of the Galatella group was established by Korolyuk et al. (1995). Farhani et al. (2018) provided further evidence that Crinitaria and Galatella, whose distinction was based on the presence or absence of sterile ray flowers (Nesom \& Robinson 2007), form a single phylogenetic group and cannot be separated based on the morphological characters. In the Galatella clade, Tripolium appears in a basal position in the latest phylogenetic reconstructions (Brouillet et al. 2009, Farhani et al. 2018) and is usually considered taxonomically distinct (e.g. Greuter \& von Raab-Straube 2008). 
The genus Pseudolinosyris was separated from Galatella on account of its subshrubby habit and longer stylar appendices (Novopokrovsky 1918). The capitula in Pseudolinosyris are constantly homogamous, without ligulate flowers, and the tubular flowers are only slightly exserted from the pappus, with very short corolla lobes. This makes plants of this group looking similar to other tribes of Asteraceae rather than to Astereae. Indeed, great confusions in the classification of this group include original descriptions of its members as belonging to Cardueae (Bornmüller 1903) or Inuleae (Bornmüller 1938, Rechinger 1955), with their subsequent reclassification (Novopokrovsky 1918, Podlech 1970, Grierson 1980).

Because of the close morphological similarity, Grierson (1982) opted for the inclusion of Pseudolinosyris into Crinitaria, whereas other authors (Tulaganova 1993, Czerepanov 1995) maintained it separate. Grierson (1982) also reduced the number of species in this group, which was not accepted by Tulaganova (1993) or Czerepanov (1995). For this reason, the current treatments for the Flora Iranica area (Grierson 1982) and for the former Soviet Union (Czerepanov 1995) are incompatible.

The present contribution aims to clarify the taxonomic position of Pseudolinosyris and the taxonomic status, nomenclature and distribution of its species, in order to stabilize its taxonomy within the Astereae. Other seemingly related taxa occurring in Afghanistan and Pakistan are also taken into account.

This revision is based on herbarium specimens collected from the whole distribution area of Pseudolinosyris, and on field observations in Kyrgyzstan. The collections of FRU and personal collections of the authors were examined de visu, and the collections of LE and MW were seen as photographs or digital images (https:// plant.depo.msu.ru/?d=P). Some type specimens and other collections were examined as digital images at https://www.jstor.org.

Diagnostic characters were assessed for variability in Pseudolinosyris and morphologically related taxa. Morphological descriptions of accepted taxa were compiled on the basis of herbarium specimens. Protologues were scrutinized and the nomenclatural code (Turland et al. 2018) was applied throughout. In all cases, typification was straightforward and the best-preserved specimens were selected among duplicates of the same gathering or syntype gatherings.

Distribution areas were revised and maps of species distributions were compiled using herbarium collections and taxonomic treatments from Kazakhstan (Terekhova 1965), Kyrgyzstan (Nikitina 1965), Tajikistan (Zhogoleva 1988), Turkmenistan (Novopokrovsky \& Tamamschian 1960, Nikitin \& Geldykhanov 1988), Uzbekistan (Bondarenko 1962), Central Asia as a whole (Tulaganova 1993), and Afghanistan and Pakistan (Grierson 1982). Altogether 90 localities were mapped. The background data were deposited at Internet Archive (https://archive.org/ details/Pseudolinosyris); for this reason, herbarium specimens are cited only exceptionally in the text.

\section{Diagnostic characters}

Pseudolinosyris shares the cylindric capitula with imbricate phyllaries with species of Galatella s. lato as assumed by Grierson (1982). The only differences from the other groups of Galatella are a higher degree of lignification of its stems and shorter corolla lobes. In agreement with Grierson (1982), we do not consider that those characters justify recognition at the generic level. Pseudolinosyris can be naturally accommodated into Galatella as a section.

Latest treatments (Tamamschian 1959, Tulaganova 1993) recognized only three taxa in this group, which can be treated as a single species, Crinitaria grimmii (Grierson 1982). Grierson (1982) accepted two further taxa of Crinitaria in Afghanistan (C. asperella and C. corymbu$\operatorname{los} a$ ), which are also characterised by a higher degree of lignification and the same type of involucres. Crinitaria corymbulosa has similar flowers and broader phyllaries with scariose margins, being distinct largely in the corymbosepaniculate inflorescence (branches oriented at wider angles), whereas the inflorescence in $C$. grimmii is paniculate with branches oriented at acute angles. Crinitaria corymbulosa is apparently closely related to $C$. grimmii and should be included in the same section. 
The second species in Afghanistan, $C$. asperella, differs from $C$. corymbulosa and $C$. grimmii in the scabrid pubescence, phyllaries with indistinct scariose margins, and broad, trinervous, dentate leaves (vs. narrow, entire leaves with a single nerve), which is a unique feature in Galatella. It also has a greater number of flowers per head (up to 10 vs. 4-6 in C. grimmii). For this reason, this species is placed into a separate but presumably related section here.

The Central Asian Pseudolinosyris grimmii, P. microcephala and P. sintenisii (Tamamschian 1959, Tulaganova 1993) differ in the size of their involucres only. The most common taxon, $P$. grimmii has 9-11 mm long involucres, whereas in P. microcephala (a narrow endemic of central Kyrgyzstan) they reach $8 \mathrm{~mm}$. This level of difference cannot be considered of high taxonomic significance in Asteraceae, and the small-headed populations occurs close to the normal-sizeheaded populations in the same country. Since the plants with different sizes of heads were not found in the same population, we accept these taxa at the subspecies level. Similarly, $P$. sintenisii differs only by its longer involucres $(14 \mathrm{~mm})$ and may be accepted as the third subspecies because of its isolated distribution in the Kopetdagh.

The other character previously used to distinguish taxa in $P$. grimmii s. lato, the prominent sessile glands, has no diagnostic value as it largely depends on the presence of the thin lanate pubescence which is highly variable and may be variously expressed or even absent in different populations of the same species.

\section{Taxonomy and nomenclature}

\section{Galatella sect. Asperifoliae Sennikov, sect. nova}

TyPE: Varthemia asperella Rech. f. \& Køie.

Suffrutices valde lignosi, asperi. Folia ovatolanceolata, trinervia, dentata. Involucri phylla vix scariosa.

Low-growing subshrubs with highly lignified, abundantly branched, ascending main trunk and numerous erect stems, nearly glabrous but scabrid. Stems branched in the upper half, sparsely leafy throughout. Leaves ovate-lanceolate, sparsely dentate, with 3 nerves, laxly appressed to stems, surface with indistinct sessile glands. Capitula numerous on long bracteose branches, cylindric or narrowly turbinate, always homogamous. Phyllaries multiseriate, imbricate, obovate, upper part not scariose, apex subacute, minutely apiculate. Flowers 7-10, tubulate, yellow, long exserted from the involucre but only slightly exceeding the pappus, corolla with very short (less than $1 \mathrm{~mm}$ ) lobes. Anthers yellow. Achenes columnar, pilose, with sessile glands. Pappus biseriate, pale brownish.

Single species: Galatella asperella.

\section{Galatella asperella (Rech. f. \& Køie)}

Sennikov, comb. nova

Varthemia asperella Rech. f. \& Køie, Biol. Skr. 8(2): 35. 1955. - Aster asperellus (Rech. f. \& Køie) Leins \& Podlech, Mitt. Bot. Staatssamml. München 8: 182. 1970. - Crinitaria asperella (Rech. f. \& Køie) Grierson in Rechinger, Fl. Iranica 145: 109. 1980. — TyPE: Afghanistan. Panjshir: Rukha, 2000 m a.s.1., 10 October 1948 M. Køie 2935 (W19560003034, lectotype designated here; isolectotypes C10007224 and C10007225).

Highly lignified subshrubs ca. $30 \mathrm{~cm}$ tall, green, covered with short rigid papillose hairs and sessile glands; main axes ascending, branching. Lateral stems numerous, suberect, evenly covered with sparse leaves, arcuately branched in the upper half, branches evenly but laxly bracteose. Stem leaves ovate-lanceolate, with 3 nerves, sparsely dentate, laxly appressed, 1.5-3 cm long, $0.4-1.5 \mathrm{~cm}$ wide. Capitula numerous on rather long branches (1-3 cm long), narrowly turbinate. Involucres ca. $10 \mathrm{~mm}$ long, imbricate, with 20-25 phyllaries. Outer phyllaries ovate, middle phyllaries ovate-oblong, inner phyllaries ovateoblong, all pale green at the base, almost without scariose margins, with brownish-green subacute main part. Flowers $7-10$, ca. $10 \mathrm{~mm}$ long. Achenes narrowly columnar, unevenly pubescent with laxly appressed hairs, surface with sessile glands. Pappus ca. $7 \mathrm{~mm}$ long, pale brownish.

Endemic to Afghanistan (Fig. 1). On rocks, at $1600-3300 \mathrm{~m}$ a.s.1. 


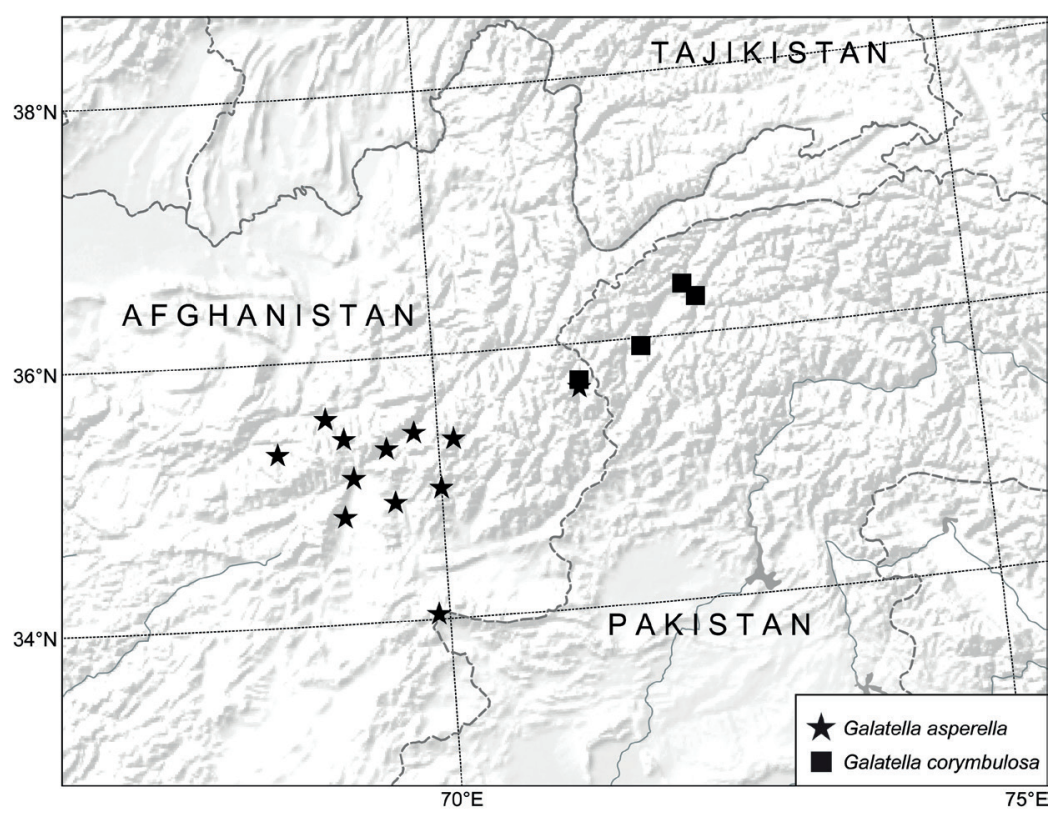

Fig. 1. Distribution of Galatella asperella and $G$. corymbulosa (based on Grierson 1982).

\section{Galatella sect. Pseudolinosyris (Novopokr.) Sennikov, comb. nova}

Pseudolinosyris Novopokr., Izv. Glavn. Bot. Sada RSFSR 18: 11. 1918. — TYPE: Linosyris grimmii Regel \& Schmalh. (lectotype designated here).

Low-growing subshrubs with highly lignified, abundantly branched, ascending main trunk and numerous erect stems, laxly and sparsely lanate or nearly glabrous. Stems branched in the upper quarter to half, densely leafy throughout. Leaves linear or linear-lanceolate, entire, with 1 (rarely 3) nerves, laxly appressed to stems, surface with distinct or indistinct sessile glands. Capitula numerous on long bracteose branches, cylindric or narrowly turbinate, always homogamous. Phyllaries multiseriate, imbricate, obovate, upper part often expanded and scariose, ciliate, apex obtuse, minutely apiculate. Flowers 4-5(6), tubulate, yellow (turning pinkish when dry), long exserted from the involucre but only slightly exceeding the pappus, corolla with very short (less than $1 \mathrm{~mm}$ ) lobes. Anthers yellow or pinkish. Styles with long (1-1.5 mm) fringed apical appendages. Achenes columnar, pilose, with sessile glands. Pappus biseriate, pale brownish.

Two species: Galatella corymbulosa and $G$. grimmii.
Galatella corymbulosa (Bornm.) Sennikov, comb. nova

Varthemia corymbulosa Bornm., Repert. Spec. Nov. Regni Veg. Beih. 108: 64. 1938. - Crinitaria corymbulosa (Bornm.) Grierson in Rechinger, Fl. Iranica 145: 109. 1980 - TyPE: Pakistan. Chitral: "In valle Mastuj infra Mastuj”, 2000 m a.s.1., 23 November 1935 G. Kerstan 2061 (HAL0081831, lectotype designated by Grierson 1982: 13; isotypes B100093709, HAL0107692).

Highly lignified subshrubs ca. $25 \mathrm{~cm}$ tall, glaucous-green, nearly glabrous, with sessile glands; main axes ascending, forming a massive trunk. Lateral stems several, erect, thin, evenly covered with leaves, branched in the upper quarter, branches at wide angle (inflorescence corymbose), ebracteose or with a few bracts only. Stem leaves narrowly oblong, with 1 or 3 nerves, entire, laxly appressed, $1.5-2.5 \mathrm{~cm}$ long, $0.3-0.8 \mathrm{~cm}$ wide. Capitula numerous on short branches (ca. $1 \mathrm{~cm}$ long), cylindric. Involucres ca. $8 \mathrm{~mm}$ long, imbricate, with 15-18 phyllaries. Outer phyllaries broadly triangular, middle phyllaries oblong-ovate, inner phyllaries oblong, all pale green with fringed narrowly scariose margins and brownish-green obtuse apical parts. Flowers 4-5, 9-10 mm long. Achenes narrowly columnar, unevenly pubescent with laxly appressed hairs, surface with sessile glands. Pappus 9-10 mm long, pale brownish. 
Afghanistan and Pakistan (Fig. 1). Mountain slopes at 2000-2300 m a.s.1.

\section{Galatella grimmii (Regel \& Schmalh.) Sennikov, comb. nova}

Linosyris grimmii Regel \& Schmalh., Acta Horti Petrop. 5: 615. 1878. - Aster grimmii (Regel \& Schmalh.) B. Fedtsch., Rastit. Turkest.: 731. 1915. - Pseudolinosyris grimmii (Regel \& Schmalh.) Novopokr., Izv. Glavn. Bot. Sada RSFSR 18: 12. 1918. - Pseudolinosyris grimmii var. glandulosa Novopokr., Izv. Glavn. Bot. Sada RSFSR 18: 12. 1918, nom. inval. (Art. 36.1a). - Crinitaria grimmii (Regel \& Schmalh.) Grierson in Rechinger, Fl. Iranica 145: 109. 1980. - TYPE: Kyrgyzstan. Chatkal Valley, "Packrack" [Barkrauk], [16] August 1876 A. Regel (LE, lectotype designated by Tamamschian 1959: 182). — NotEs. On herbarium labels and in the protologue (Regel 1878) the type locality "Packrack" was indicated as situated along Chirchik River (Uzbekistan). Its correct situation along Chatkal River (Kyrgyzstan) was given in Lipsky (1905) and Novopokrovsky (1918) but overlooked in later publications (Tamamschian 1959, Grierson 1982). The species name was chosen to honour the "intimate friend" of Albert Regel, who was named "Richard Grimm" in the protologue; most likely, this friend was Johann Alexander Richard von Grimm (18471903), Active State Councillor, who lived in St. Petersburg, studied economy at the Dorpat University (now Tartu, Estonia) and worked in St. Petersburg as a teacher at Petrischule and then as a librarian at the Imperial Service.

Linosyris grimmii var. macrostyla Regel \& Schmalh., Izv. Imp. Obshch. Lyubit. Estestv. Moskovsk. Univ. 34(2): 43. 1881. - TYPE: Uzbekistan/Tajikistan. "Sangi-Juman" Pass, 5 September 1870 O. Fedtschenko (LE, holotype). Note. The type locality is a pass situated on the present-day border between Uzbekistan and Tajikistan.

Linosyris capusii Franch., Ann. Sci. Nat., Bot., sér. 6, 16: 306. 1883. - Pseudolinosyris capusii (Franch.) Novopokr., Izv. Glavn. Bot. Sada RSFSR 18: 12. 1918. — Pseudolinosyris grimmii var. eglandulosa Novopokr., Izv. Glavn. Bot. Sada RSFSR 18: 12. 1918, nom. inval. (Art. 36.1a). - Aster franchetii Novopokr., Izv. Glavn. Bot. Sada RSFSR 18: 12. 1918, nom. inval. (Art. 36.1a). — TyPE: Kyrgyzstan. "Karakoroum" [Kara-Korum River, a tributary of Chatkal River], 28 August 1881 G. Capus (P00711640, lectotype designated here; isolectotype P00711639).

Varthemia platylepis Rech. f. \& Køie, Biol. Skr. 8(2): 37. 1955. - Type: Afghanistan. Kabul: Hauz-i Mahiha, 2500 m a.s.1., 11 July 1948 M. Køie 2384 (W19560003040, lectotype designated here; isolectotypes C10007226, C10007227, C10007228, BR0000005537501, E00556615). — Notes: The authorship of the text under Varthemia ("Species excludendae") containing new combinations in Crinitaria, which was published in Flora Iranica vol. 145 (Grierson 1980), was not explicitly stated. That small appendix apparently is not part of the treatment of Varthemia which was authored by Rechinger (1980). For the purpose of nomenclature, its authorship should be treated as not stated in the original publication; in the absence of internal evidence, the treatment by Grierson (1982) should be accepted as providing external evidence for the authorship of the appendix and new combinations as ascribed therein.

\section{Galatella grimmii subsp. grimmii}

Highly lignified subshrubs $25-30 \mathrm{~cm}$ tall, grayish-green or green, with or without a thin sparse pubescence, with small or rather large, indistinct or prominent sessile glands; main axes ascending, branching up to the top. Lateral stems numerous, suberect, thin, ribbed, evenly and densely covered with leaves, branched in the upper quarter, branches at acute angle (inflorescence paniculate), laxly bracteose or nearly without bracts. Stem leaves linear or lanceolate, with 1 nerve, entire, very laxly appressed, $1.5-3.5 \mathrm{~cm}$ long, $0.2-0.5 \mathrm{~cm}$ wide. Capitula several on long branches (1.5-5 cm long), cylindric or narrowly turbinate. Involucres 9-11 mm long, imbricate, with 20-25 phyllaries. Outer phyllaries triangular or triangular-ovate, middle phyllaries ovate, inner phyllaries oblong, all pale green with fringed scariose margins and green acute triangular apical part. Flowers 4-5(6), ca. $10 \mathrm{~mm}$ long. Achenes narrowly columnar, unevenly pubescent with laxly appressed hairs, surface with sessile glands. Pappus 9-10 mm long, pale brownish.

Afghanistan, Kazakhstan, Kyrgyzstan, Tajikistan, Turkmenistan, Uzbekistan (Fig. 2). Mountain slopes at 1600-2700 $\mathrm{m}$ a.s.1.

\section{Galatella grimmii subsp. microcephala (Novopokr.) Sennikov, comb. nova (Fig. 3)}

Pseudolinosyris capusii var. microcephala Novopokr., Izv. Glavn. Bot. Sada RSFSR 18: 13. 1918. - Pseudolinosyris microcephala (Novopokr.) Tamamsch. in Schischkin, Fl. USSR 25: 182. 1959. - TYPE: Kyrgyzstan. Left side of Kökömeren River at its confluence with Suusamyr and Jumgol rivers, 27 July 1915 M.D. Spiridonov 41.523 (LE, lectotype designated here; isolectotype LE). - Note. The lectotype bears the number " 41.523 ", whereas on the isolectotype the number is abbreviated to " 523 ".

Highly lignified subshrubs ca. $30 \mathrm{~cm}$ tall, grayish-green of thin lanate pubescence, with small, indistinct sessile glands; main axes 


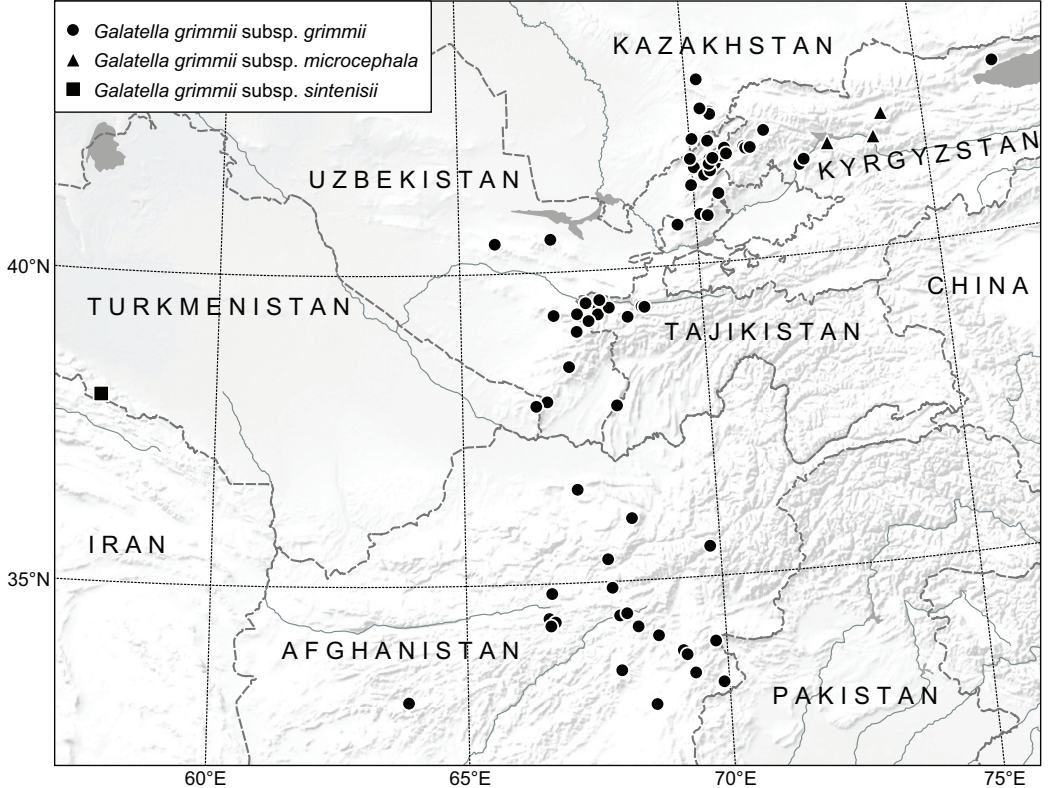

Fig. 2. Distribution of Galatella grimmii s. lato (based on Grierson 1982, Zhogoleva 1988, Nikitin \& Geldykhanov 1988, and specimen data). ascending, abundantly branching up to the top. Lateral stems numerous, suberect, thin, evenly covered with leaves, branched in the upper quarter, branches at acute angle (inflorescence paniculate), evenly but laxly bracteose. Stem leaves linear, with 1 nerve, entire, laxly appressed, 1-1.5 cm long, 0.1-0.15(2) cm wide. Capitula numerous on short branches (ca. $1 \mathrm{~cm}$ long), shortly cylindric or narrowly turbinate. Involucres ca. $8 \mathrm{~mm}$ long, imbricate, with 15-20 phyllaries. Outer phyllaries triangular-ovate, middle phyllaries ovate, inner phyllaries oblong, all pale green with fringed scariose margins and green acute triangular apex. Flowers 4-5, ca. $9 \mathrm{~mm}$ long. Achenes narrowly columnar, unevenly pubescent with laxly appressed hairs, surface with sessile glands. Pappus 9-10 mm long, pale brownish.

Endemic to Kyrgyzstan (Fig. 2); found in small mountain ranges situated along the Naryn and Kökömeren rivers (Sary-Kamysh, Taktalyk, Jumgol, Kabak-Too). Mountain slopes at 2000$2700 \mathrm{~m}$ a.s.1.

Specimens eXAmined: Kyrgyzstan. S side of Suusamyr Range, Kavük-Suu River near Sary-Kamysh, 31 July 1989, M.G. Pimenov \& E.V. Kluykov 89 (MW0881731 and MW0881732); N side of Taktalyk Range, 27 July 1973, R.A. Aidarova et al. (FRU); Kabak-Too Mts., versicolour denudations along Jumgol River at its confluence with Kökömeren River, near Ak-Tash Village, slopes with hemi- savannah, 1575 m a.s.1., 17 August 2013 , A.N. Sennikov \& G.A. Lazkov 304 (H1762957).

\section{Galatella grimmii subsp. sintenisii (Bornm.) Sennikov, comb. nova}

Staehelina sintenisii Bornm., Mitt. Thüring. Bot. Vereins, n.s., 18: 50. 1903. - Pseudolinosyris sintenisii (Bornm.) Tamamsch. in Schischkin, Fl. USSR 25: 183. 1959. — TYPE: Turkmenistan. Ahal: "Germab inter Skobelewka et Kulkulab", 31 August 1900 P. Sintenis 1175 (LE, lectotype designated by Tamamschian 1959: 183; isolectotypes G00223532, JE00015415, LD1228348 and LD1219569).

Highly lignified subshrubs ca. $30 \mathrm{~cm}$ tall, grayish-green of thin lanate pubescence, with small, indistinct sessile glands; main axes ascending, long lignified, abundantly branching up to the top. Lateral stems numerous, suberect, thin, evenly but sparsely covered with leaves, little branched at acute angle in the upper third part, branches at acute angle (inflorescence paniculate), evenly but laxly bracteose. Stem leaves linear, 1-nerved, entire, laxly appressed, 3-5 cm long, $0.2-0.3 \mathrm{~cm}$ wide. Capitula rather few on long branches (up to $5 \mathrm{~cm}$ long), cylindric. Involucres ca. $14 \mathrm{~mm}$ long, imbricate, with 20-25 phyllaries. Outer phyllaries ovate, middle phyllaries oblong-ovate, inner phyllaries oblong, all pale green with fringed scariose margins and green 


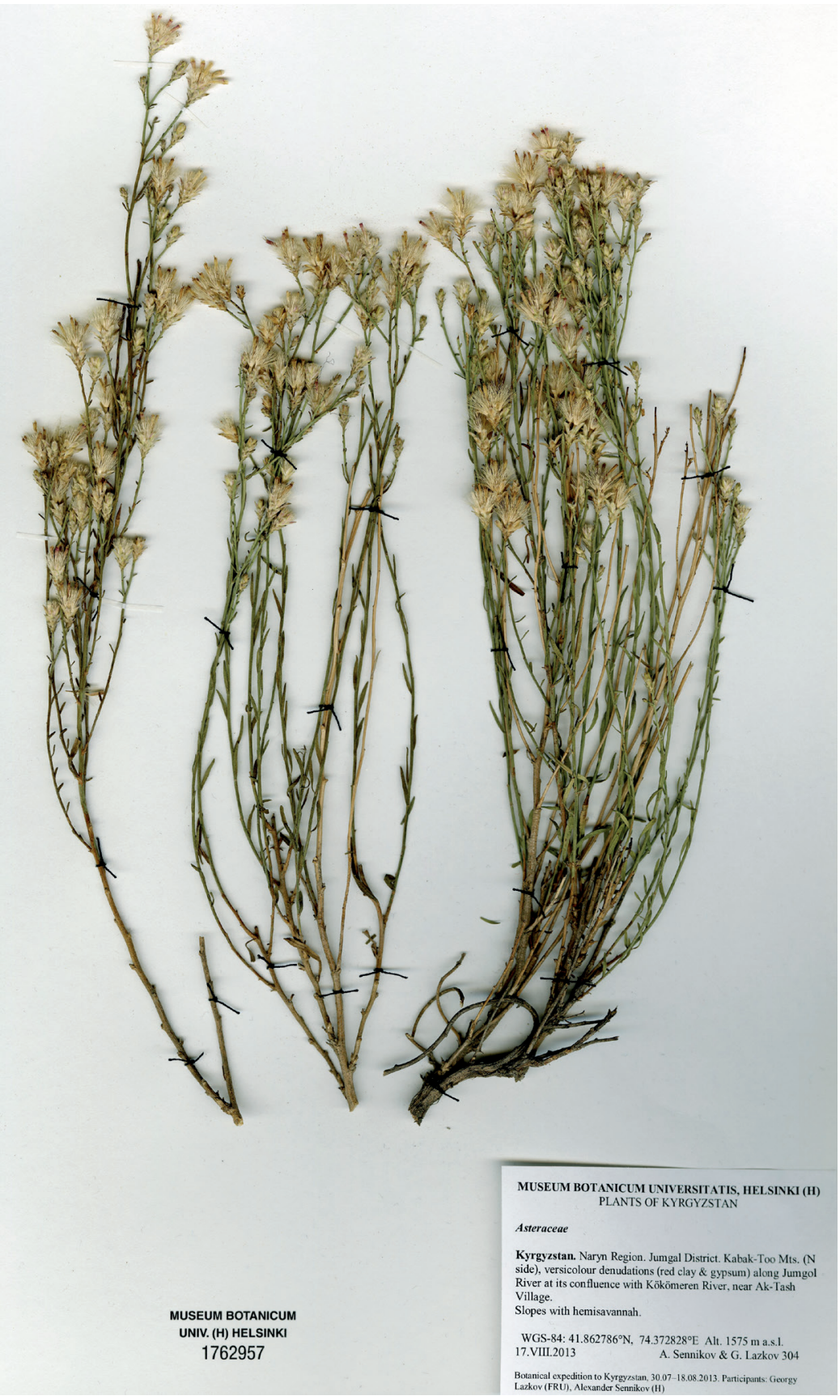

Fig. 3. Representative specimen of Galatella grimmii subsp. microcephala.
Identification key to the species and subspecies of Galatella sect. Asperifoliae and $G$. sect. Pseudolinosyris

Achenes narrowly columnar, unevenly pubesce with laxly appressed hairs, surface with sessile glands. Pappus 9-10 mm long, pale brownish.

Endemic of Turkmenistan (Fig. 2), known from the holotype only (Nikitin \& Geldykhanov 1988). Mountain slopes at ca. $1000 \mathrm{~m}$ a.s.l.
1. Leaves ovate-lanceolate, 3-nerved, sparsely dentate, surface scabrid; phyllaries not scariose at apex . G. asperella

1. Leaves linear or linear-lanceolate, 1-(rarely 3)-nerved, entire, surface not scabrid; phyllaries scariose at apex .. 2 
2. Branch angles wide, inflorescence corymbose-paniculate G. corymbulosa

2. Branch angles acute, inflorescence narrowly paniculate (G. grimmii) ... 3

3. Involucres $14 \mathrm{~mm}$ long ...... G. grimmii subsp. sintenisii

3. Involucres $8-11 \mathrm{~mm}$ long ........

4. Involucres up to $8 \mathrm{~mm}$ long G. grimmii subsp. microcephala

4. Involucres 9-11 mm long .... G. grimmii subsp. grimmii

\section{Notes}

The distribution of Galatella sect. Pseudolinosyris in Central Asia and the Himalayas largely follows the areas of greater precipitation (according to the WORLDCLIM data available at https://www.worldclim.org/). As many other taxa occurring in the Western Tian-Shan, species of this section are absent from the Fergana Range of the Tian-Shan, and from the eastern part of the Turkestan Range and the Alay Range of the Pamir-Alay (Kamelin 2002).

Besides Galatella sect. Pseudolinosyris and $G$. sect. Asperifoliae, the other species of Galatella with longer corolla lobes and a lesser lignification of stems may be distributed in three sections. Galatella sect. Galatella (type: Aster punctatus Waldst. \& Kit.; designated by Tzvelev 1959: 138; syn. G. sect. Fastigiatae) includes Eurasian species with narrow green phyllaries, of which the outer ones are much shorter than the innermost. Galatella sect. Crinitaria (type: Chrysocoma villosa L.; designated by Tzvelev 1959: 178; syn. G. sect. Chrysocomella nom. illeg.) includes two Eurasian species ( $G$. tatarica, G. villosa) with broader pale imbricate phyllaries. The type of the latter section is not automatically Crinita punctata Moench = Galatella punctata (Waldst. \& Kit.) Nees as recently assumed (Tzvelev 1994, Flann et al. 2010); it was selected from two other species mentioned by Cassini (1825) in the protologue. Galatella sect. Linosyris (type: Chrysocoma linosyris L.) is monotypic and includes only G. linosyris with narrowly linear phyllaries, of which the outer ones approach the innermost phyllaries in length.

The taxonomic position of $G$. sect. Xylogalatella and $G$. sect. Oreophilon (3 species in eastern Central Asia) has not been re-assessed due to the lack of material.

\section{Acknowledgements}

We are grateful to Denis Melnikov (St. Petersburg) for kind communication of specimen images and observations from LE, and to Sampsa Lommi (Helsinki) who made the maps.

\section{References}

Bondarenko O.N. [Бондаренко O.H.] 1962: Pseudolinosyris Novopokr. - In: Vvedensky A.I. [Введенский А.И.] (ed.) [Flora of Uzbekistan, 6]: 43. Academy of Sciences of the Uzbek SSR, Tashkent. [In Russian].

Bornmüller J. 1903: Plantae nonnullae ex Asia Media novae, I. - Mitteilungen des Thüringischen Botanischen Vereins, n.s., 18: 49-54.

Bornmüller J. 1938: Botanische Ergebnisse der Deutschen Hundukusch-Expedition 1935. Compositae, I. - Repertorium Specierum Novarum Regni Vegetabilis. Beihefte 108(1): 36-70, Taf. 4-24.

Brouillet L., Lowrey T.K., Urbatsch L., Karaman-Castro V., Sancho G., Wagstaff S. \& Semple J.C. 2009: Astereae. — In: Funk V.A., Susanna A., Stuessy T. \& Bayer R. (eds.), Systematics, evolution, and biogeography of the Compositae: 589-629. IAPT, Vienna.

Cassini A.H.G. de 1825: Paquerette, Bellis. - In: Cuvier J.L.N.F. (ed.), Dictionnaire des sciences naturelles 37: 452-495. F.G. Levrault, Strasbourg \& Paris, Le Normant, Paris.

Czerepanov S.K. 1995: Vascular plants of Russia and adjacent states (the former USSR). — Cambridge University Press, Cambridge.

Farhani T., Kazempour-Ozaloo F., Zare-Maivan H. \& Mozaffarian V. 2018: Evolutionary history of the tribe Astereae in the Flora Iranica area: systematic implications. Phytotaxa 379: 95-117.

Flann C., Greuter W. \& Hind D.J.N. 2010: Cassini's Compositae genera: a nomenclatural and taxonomic assessment. - Taxon 59: 1206-1244.

Greuter W. \& von Raab-Straube E. (eds.) 2008: MedChecklist. A critical inventory of vascular plants of the circum-mediterranean countries, vol. 2: Dicotyledones (Compositae). - OPTIMA Secretariat, Palermo \& Med-Checklist Trust of OPTIMA, Genève \& Euro+Med Plantbase Secretariat, Berlin.

Grierson A.J.C. 1980: Varthemia DC.: Species excludendae. - In: Rechinger K.H. (ed.), Flora Iranica 145: 109. Akademische Druck- und Verlagsanstalt, Wien.

Grierson A.J.C. 1982: Crinitaria Cass. - In: Rechinger K.H. (ed.), Flora Iranica 154: 11-14. Akademische Druckund Verlagsanstalt, Wien.

Kamelin R.V. [Камелин Р.В.] 2002: [A brief description of the plant vegetation in Kirgizia]. - In: Pimenov M.G. \& Kluykov E.V. [Пименов М.Г. \& Клюйков Е.В.], [Umbelliferae of Kirgizia]: 5-18. KMK Scientific Press, Moscow. [In Russian].

Korolyuk E., Makunin A. \& Matveeva T. 1995: Relationships and generic delimitation of Eurasian genera of the subtribe Asterinae (Astereae, Asteraceae) using molecu- 
lar phylogeny of ITS. - Turkish Journal of Botany 39: 808-824.

Lipsky V.I. [Липский В.И.] 1905: [Flora of Central Asia, i.e. Russian Turkestan and the khanates of Bukhara and Khiva 3. Botanical collections from Central Asia]. Trudy Tiflisskago Botanicheskago Sada 7: 339-841. [In Russian].

Nesom G. \& Robinson H. 2007: Tribe Astereae Cass. - In: Kadereit J.W. \& Jeffrey C. (eds.), The families and genera of vascular plants, vol. 8: 284-342. Springer, Berlin.

Nikitin V.V. \& Geldykhanov A.M. [Никитин В.В. \& Гельдыханов А.M.] 1988: [Manual of vascular plants of Turkmenistan]. — Science Publishers, Leningrad. [In Russian].

Nikitina E.V. [Никитина E.B.] 1965: Pseudolinosyris Novopokr. - In: Vykhodtsev I.V. [Выходцев И.В.] (ed.), [Flora of the Kirgiz SSR, 11]: 35. Science Publishers, Frunze. [In Russian].

Novopokrovsky I.V. [Новопокровский И.В.] 1918: [Тахоnomic notes on Astereae, 2. The new genus Pseudolinosyris Novopokrovsky]. — Izvestiya Glavnogo Botanicheskogo Sada RSFSR 18: 7-13. [In Russian].

Novopokrovsky I.V. \& Tamamschian S.G. [Новопокровский И.В. \& Тамамшян С.Г.] 1960: Pseudolinosyris Novopokr. - In: Nikitin V.V. [Никитин B.B.] (ed.), [Flora of the Turkmen SSR, 7]: 25-26. Academy of Sciences of the Turkmen SSR, Ashkhabad. [In Russian].

Podlech D. 1970: Neue und bemerkenswerte Arten aus Nordost-Afghanistan, II (Beiträge zur Flora von Afghanistan, V). - Mitteilungen aus der Botanischen Staatssammlung München 8: 165-189.

Rechinger K.H. 1955: Compositae. — Biologiske Skrifter udgivet af Det Kongelige Danske Videnskabernes Sels$k a b$ 8(2): 5-215.

Rechinger K.H. 1980: Varthemia DC. - In: Rechinger K.H. (ed.), Flora Iranica 145: 107-109. Akademische Druckund Verlagsanstalt, Wien.
Regel E. 1878: Descriptiones plantarum novarum vel minus cognitarum. Fasciculus VI. Plantae regiones turkestanicas incolentes, secundum specimina sicca a Regelio et Schmalhausenio determinatae. - Acta Horti Petropolitani 5: 577-620.

Tamamschian S.G. [Тамамшян С.Г.] 1959: Pseudolinosyris Novopokr. - In: Schischkin B.К. [Шишкин Б.К.] (ed.), [Flora of the USSR, 25]: 180-183. Academy of Sciences of the USSR, Moscow \& Leningrad. [In Russian].

Terekhova V.I. [Терехова В.И.] 1965: Pseudolinosyris Novopokr. - In: Pavlov N.V. [Павлов H.B.] (ed.), [Flora of Kazakhstan, 8]: 337-338. Science Publishers, Alma-Ata. [In Russian].

Tulaganova M.T. [Туляганова M.T.] 1993: Pseudolinosyris Novopokr. - In: Adylov T.A. \& Zuckerwanik T.I. [Адылов Т.А. \& Цукерваник Т.И.] (eds.), Conspectus florae Asiae Mediae 10: 480-481. Science Publishers, Tashkent. [In Russian].

Turland N.J., Wiersema J.H., Barrie F.R., Greuter W., Hawksworth D.L., Herendeen P.S., Knapp S., Kusber W.-H., Li D.-Z., Marhold K., May T.W., McNeill J., Monro A.M., Prado J., Price M.J. \& Smith G.F. (eds.) 2018: International Code of Nomenclature for algae, fungi, and plants (Shenzhen Code) adopted by the Nineteenth International Botanical Congress Shenzhen, China, July 2017. - Regnum Vegetabile 159: 1-254.

Tzvelev N.N. [Цвелев Н.H.] 1959: Galatella Cass., Linosyris Cass. - In: Schischkin B.К. [Шишкин Б.К.] (ed.), [Flora of the USSR, 25]: 138-180. Academy of Sciences of the USSR, Moscow \& Leningrad. [In Russian].

Tzvelev N.N. [Цвелев Н.Н.] 1994: Galatella Cass. — In: Tzvelev N.N. [Цвелев H.H.] (ed.), [Flora of the European part of the USSR, 7]: 189-194. Science Publishers, Saint-Petersburg. [In Russian].

Zhogoleva E.P. [Жоголева Е.П.] 1988: Pseudolinosyris Novopokr. - In: Kinzikaeva G.K. [Кинзикаева Г.К.] (ed.), [Flora of the Tajik SSR, 9]: 205-206. Science Publishers, Leningrad. [In Russian]. 